J. Perinat. Med. 2 (1974) 106

\title{
Quantitative relationships between slowing of the fetal heart rate and changes in base-excess in the second stage of labor
}

\author{
E. Kastendieck, W. Künzel, P. Zimmermann \\ Department of Obstetrics \& Perinatology, Medical College, Hannover
}

Received September 17, 1973. Accepted November 27, 1973.

The partial pressure of oxygen in the blood of the scalp and that of the umbilical artery of the fetus is lowered during the first and second stage of labor, if there is a slowing of the heart rate in conjunction with uterine contractions ( $\mathrm{CAL}$ DEYRO-BARCIA et al. [2]; KüNZEL [4]). In animal experiments the reduction of uterine blood flow was shown to be a cause of this deceleration (JuNGE, KüNZEL, KLÖCK [3]). Since the duration of the reduced blood flow corresponds well to the duration of the deceleration and hypoxia, it might be assumed that the dip area is an indication of the hypoxia and the resulting metabolic acidosis. This is even more probable since Tipton and Shelley [6] have shown a definite relationship between the dip area and clinical parameters.

We have attempted to find out whether there is a quantitative relationship between the dip areas measured before birth and the metabolic changes in the blood of the fetus so that an increase in the deficit in the fetal blood can be estimated more precisely. The examinations showed a good relationship between such a dip area and the increased base excess in the fetal blood.

\section{Material and measurements}

The examinations were carried out on an unselected group of 26 women 26 minutes $(S D=22)$ before the birth of the child. The value of the base excess was measured, both in scalp blood and in the blood of the umbilical artery, according to the method of Astrup et al. [1] and SIGGAARD-ANDERSEN [5]. The increase in base deficit was calculated from the difference in base-excess between scalp blood $\left(\mathrm{BE}_{\mathrm{S}}\right)$ and the blood in the umbilical artery $\left(\mathrm{BE}_{\mathrm{U}} \mathrm{A}\right)$. This

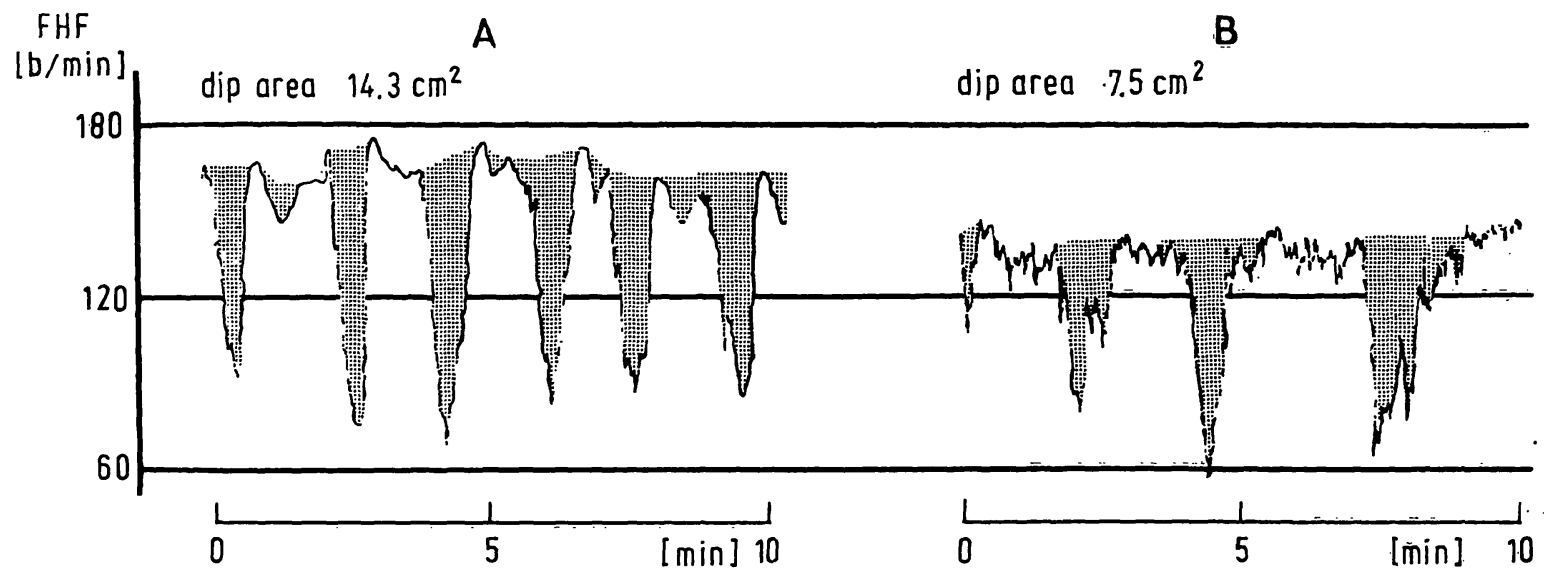

Fig. 1. Comparison of two electrocardiograms with decelerations before birth. " $A$ " shows a basal fetal heart rate of 170 per minute, with 6 decelerations in 10 minutes. In " $B$ " the level of the fetal heart rate is 130 to 140 per minute and the number of decelerations fewer. The resulting dip area (shaded) during the 10 minutes of observations was $14.3 \mathrm{~cm}^{2}$ in " $\mathrm{A}$ " and $7.5 \mathrm{~cm}^{2}$ in " $\mathrm{B}$ ". 
procedure is permissible because there is a reliable relationship between these two values $\left(B E_{S}-B_{U} A\right)$, as shown by Teramo [7]). No attempt was made to correct these values according to the actual oxygen saturation. The dip area was measured with the aid of a Polar-Planimeter (OTr Manufacturers) between the time of the micro blood examination and the birth of the child. The calculated dip area is shaded in Figs. $1 \mathrm{~A}$ and $1 \mathrm{~B}$.

The fetal E. C. G. was recorded directly with electrodes and converted to a recording of the fetal heart rate by a commercial instrument.

\section{Results}

During the period of the examination the planimetric dip area mounted to $0.63 \mathrm{~cm}^{2} \times \mathrm{min}^{-1}$ $(\mathrm{SD}=0.4)$. At the beginning of the examination the value of the base excess was $-3.8 \mathrm{meq} / 1$ $(\mathrm{SD}=2.2)$ and dropped to $-7.3 \mathrm{meq} / \mathrm{l}(\mathrm{SD}=$ 3.7) during the last phase of the second stage. This drop corresponds to an average loss of base of $2.0 \mathrm{meq} / 1(\mathrm{SD}=\mathbf{2 . 3})$ in 10 minutes.

In Fig. 2 the increased base deficit, i. e. the difference between the base-excess in fetal scalp blood and that in the blood of the umbilical artery, is shown by the area of the dip. The relationship shows that, for instance, a dip area

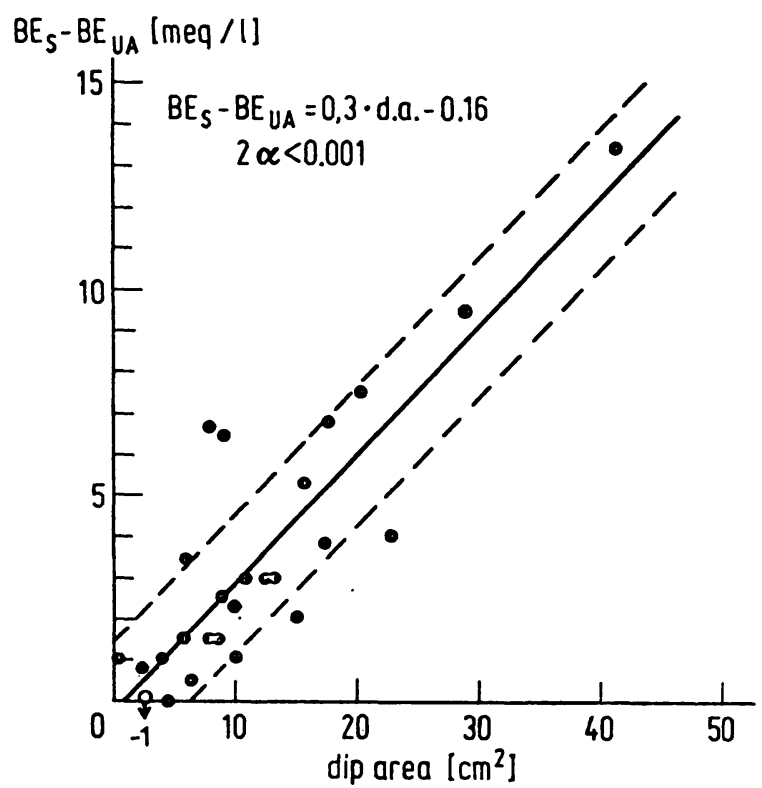

Fig. 2. The difference between the base excess in fetal scalp blood $\left(B E_{S}\right)$ and in the blood of the umbilical artery $\left(B E_{U A}\right)$ as a function of the dip area. As the dip area increases, the base deficit in the blood rises proportionately of $40 \mathrm{~cm}^{2}$ results in a base deficit of approximately $12 \mathrm{meq} / \mathrm{l}$, while with a smaller area of $10 \mathrm{~cm}^{2}$ a base loss of approximately $3 \mathrm{meq} / \mathrm{l}$ is to be expected. The period during which the dip area has been measured has not been taken into consideration, but should it be desired to include it into the results of the examination, then the following formula would result: $\triangle \mathrm{BE} \times \mathrm{min}^{-1}=$ $0.4 \times$ d. a. $\times \min ^{-1}-0.04(2 \alpha<0.001)$.

Thus for instance, if as in Fig. $1 \mathrm{~A}$ the dip area measures $14 \mathrm{~cm}^{2}$ per 10 minutes, the the buffered base is reduced by $5 \mathrm{meq} / \mathrm{l}$ in these 10 minutes, while if the dip area is as is shown in Fig. 1B, then a base loss of $2.5 \mathrm{meq} / \mathrm{l}$ is to be expected in 10 minutes.

\section{Discussion}

The dip area (d. a. $\mathrm{cm}^{2}$ ) is determined by the amplitude and duration of the decelerations and the number of such dips during a unit of time. Fig. 1 A shows that with a high basal heart rate and 6 decelerations (in conjunction with uterine contractions) within 10 minutes the area would measure $14 \mathrm{~cm}^{2}$ while, with a lower basal heart rate and fewer decelerations during the same period, only an area of $7 \mathrm{~cm}^{2}$ was observed.

These observations make it clear that decelerations towards the end of the second stage, regardless of their type, affect the buffered base in the fetal blood. An increased base deficit corresponds closely to the dip area. The value of the base excess is proportionate to the dip area (Fig. 2), and the regression curve runs through zero.

Our results for the final phase of the second stage are of special clinical significance because they make it possible to estimate fetal acidosis prior to birth. They enable us to judge the state of the fetus by feeding the record of the fetal heart beat into a computer. At the moment, this only applies to the final phase, and further work will have to show what changes in the base excess are caused by decelerations during the first stage of labor, and especially their relationship to the basal level of the heart rate. In this connection there is also the interesting problem as to whether the passage of lactate from the mother to the fetus can lead to fetal acidosis, and if so, how the amount can possibly be measured. 


\section{Summary}

Experiments on animals and in the human have shown that fetal cardiac decelerations in conjunction with uterine contractions are an expression of hypoxia. In this paper an attempt has been made to correlate the dip areas with fetal loss of base. The value of base excess 26 minutes $(\mathrm{SD}=22)$ before birth was measured in 26 parturients in the blood of both the fetal scalp and the umbilical artery. The difference in base excess between these two measurements was related to the planimetrically determined dip area.

The increase in base deficit is closely related to the dip area $\left(\mathrm{BE}_{\mathrm{S}}-\mathrm{BE}_{\mathrm{UA}}\right)=0.3 \times$ d. a. $-0.16\left(2 \alpha^{-}<0.001\right)$.
There is a distinct connection between these two parameters. This means that with a dip area of $40 \mathrm{~cm}^{2}$ a base loss of $12 \mathrm{meq} / \mathrm{l}$ is to be expected, while there are no changes in the buffered base of the fetal blood as long as there are no decelerations.

These observations enable an estimate of the buffered base loss in fetal blood at the end of the second stage of labor. The possible role of a placental passage of lactate has not been taken into consideration.

Keywords: Second stage of labor, dip area, fetus, fetal heart rate, acid-base metabolism.

\section{Zusammenfassung}

Quantitative Beziehungen zwischen Herzfrequenzverlangsamungen und Veränderungen im Base-Excess am Ende der Austreibungsperiode

Tierexperimentelle Untersuchungen und Messungen beim Menschen zeigen, daß die wehenabhängigen Herzfrequenzverlangsamungen Ausdruck einer Hypoxie sind.

Mit den vorliegenden Untersuchungen wurde geprüft, ob die Fläche der Dezelerationen zum Basenverlust des Feten korreliert.

Bei 26 Gebärenden wurde der Base-Excess-Wert $26 \mathrm{~min}$ $(\mathrm{SD}=22)$ vor Geburt und im Nabelarterienblut bestimmt. Die Differenz im Base-Excess zwischen diesen beiden Messungen wurde zur planimetrierten Dezelerationsfläche in Beziehung gesetzt.
Die Zunahme des Basen-Defizits ist zur Dezelerationsfläche eng korreliert $\left(\mathrm{BE}_{\mathrm{S}}-\mathrm{BE}_{\mathrm{UA}_{\mathrm{A}}}\right)=0.3 \times \mathrm{DF}-0.16$ $(\alpha<0.001)$. Es besteht eine Proportionalität zwischen beiden Parametern. Das bedeutet, daß bei einer Dezelerationsfläche von $40 \mathrm{~cm}^{2}$ mit einem Basenverlust von etwa $12 \mathrm{mäq} / \mathrm{l} \mathrm{zu}$ rechnen ist, während bei fehlenden Dezelerationen keine Änderungen im Puffer-Basen-Bestand des fetalen Blutes erfolgen.

Die vorliegenden Befunde erlauben nunmehr die Ausbildung des Puffer-Basen-Verlustes im fetalen Blut am Ende der Austreibungsperiode abzuschätzen. Der materne Laktatübertritt bleibt dabei unberücksichtigt.

Schlüsselwörter: Austreibungsperiode, Dezelerationsfläche, Fetus, Herzschlagfrequenz, Säure-Basen-Haushalt.

\begin{abstract}
Résumé
Relations quantitatives entre les ralentissements de la fréquence cardiaque et les variations de l'excès de base en fin de période d'expulsion

Les expérimentations animales et les mesures effectuées sur l'être humain montrent que les ralentissements de la fréquence cardiaque dûs aux contractions utérines sont l'expression d'une hypoxie.

Les analyses présentes ont été faites dans le but de prouver s'il existe une corrélation entre la surface des décélérations et la perte de base chez le foetus.

On a déterminé chez 26 femmes enceintes la valeur d' excès de base $26 \mathrm{~min}(\mathrm{SD}=22)$ avant la naissance et dans le sang artériel ombilical, puis comparé la différence d' excès de base entre ces deux mesures avec la surface de décélération planimétrée.
\end{abstract}

L'accroissement de l'excès de base négatif est en rapport étroit avec la surface de décélération $\left(B E_{S}-B E_{U A}\right)=$ 0.3 . d. a. $-0.16(2<0.001)$. Il existe une proportionnalité entre les deux paramètres. Ceci signifie que pour une surface de décélération de $40 \mathrm{~cm}^{2}$, il faut ascompter une perte de base d'environ $12 \mathrm{meq} / \mathrm{l}$, tandis qu'en cas $\mathrm{d}^{\prime}$ absence de décélérations, on n'observe aucune variation de la réserve de base tampon du sang foetal.

Les résultats présents permettent désormais d'évaluer la formation de perte de base tampon dans le sang foetal en fin de période d'expulsion. Il n'a pas été tenu compte ici du transfert de lactate maternel.

Mots-clés: Période d'expulsion, surface de décélération, foetus, fréquence cardiaque, réserve acidobasique. 


\section{Bibliography}

[1] Astrup, P., K. Jørgensen, O. SiggaArd-Andersen, K. ENGEL: The acid-base metabolism. A new approach Lancet I (1960) 1035

[2] Caldeyro-Barcia, R., C. Casacuberta, R. Rustos, G. Guissi, L. Gulin, L. Escarenca, C. Mendez-Bauer: Correlation of intrapartum changes in fetal heart rate with fetal blood oxygen and acid-base-state. In: Adamsons, K.: Diagnosis and Treatment of Fetal Disorders, Springer, Heidelberg 1967

[3] Junge, H. D., W. Künzel, F. K. Klöck: Die Dynamik der fetalen Herzfrequenzregulation bei akuter Drosselung der uterinen Durchblutung. In: DuDENhausen, J. W., E. Saling: Perinatale Medizin Band III. 4. Deutscher Kongreß für Perinatale Medizin, Berlin 1971. Thieme, Stuttgart 1973
[4] KüNzel, W.: Die Beziehung zwischen der Herzfrequenz des Feten und dem $\mathrm{PO}_{2}, \mathrm{PCO}_{2}$ und $\mathrm{pH}$ im fetalen Blut während der Eröffnungsperiode und am Ende der Austreibungsperiode. Z. Geburtsh. Perinat. 176 (1972) 276

[5] Siggaard-Andersen, O.: The pH, log $\mathrm{PCO}_{2}$ blood acid-base nomogramm revised Scand. J. Clin. Lab. Invest. 14 (1962) 598

[6] Tipton, R. H., T. Shelley: An index of fetal welfare in labour. J. obstet. Crynaec. Brit. Cwlth. 78 (1971) 702

[7] Teramo, K.: The validity of fetal capillary blood samples during labour. Gynaecologia 167 (1969) 511

Dr. E. Kastendicck,

Priv. Doz. Dr. W. Künzel

Frauenklinik der Medizinischen Hochschule

Pasteurallee 5

D-3000 Hannover/Germany 